\title{
KRYMINALISTYCZNA ANALIZA PRZYCZYN ŚMIERCI MARILYN MONROE
}

\begin{abstract}
Streszczenie. Autorka przeanalizowała błędy i zaniedbania popełnione w śledztwie dotyczącym śmierci Marilyn Monroe. W jaki sposób zmarła artystka? Czy było to zabójstwo czy samobójstwo? Badaczka odtworzyła okoliczności jej ostatnich chwil życia. Referat stanowi również analizę profilu psychologicznego aktorki. Praca nie zawiera gotowych odpowiedzi na postawione wyżej pytania, a raczej ma na celu skłonić odbiorcę do analizy.
\end{abstract}

Słowa kluczowe: Marilyn Monroe, zabójstwo, samobójstwo, dowód, sekcja zwłok.

Okoliczności śmierci Marilyn Monroe do dnia dzisiejszego nie zostały do końca wyjaśnione. Istnieje wiele niejasnych wątków i elementów, które się wzajemnie wykluczają. Nie wiadomo, czy śmierć artystki nastąpiła w wyniku samobójstwa, nieszczęśliwego wypadku czy zabójstwa. Studium tego przypadku jest wielowątkowe i opiera się na analizie poszczególnych teorii dotyczących śmierci artystki. Autorka najpierw opisuje daną teorię, a następnie wskazuje w niej nieprawidłowości i błędy.

\section{PRZYCZYNA ŚMIERCI MARILYN MONROE}

W raporcie koronera jako przyczynę śmierci podano ,prawdopodobne samobójstwo" . Jeżeli przyjęta wersja oficjalna nie była prawdziwa, nie są znane motywy ewentualnej zbrodni. Istnieje wiele domysłów podsycanych przez media. Od śmierci aktorki minęło wiele lat, ale nadal nie ma odpowiedzi na pytanie, $w$ jaki sposób zmarła. Jej śmierć wciąż budzi emocje. Czy stan psychiczny Marilyn Monroe był na tyle niestabilny, że była ona zdolna do popełnienia samobójstwa?

Gdzie pojawiają się pytania bez odpowiedzi, tam rodzi się przestrzeń dla różnego rodzaju teorii spiskowych. B. Sygit w pracy naukowej $O$ teoriach spiskowych ze stanowiska kryminalistyki stwierdził: „Nie można bowiem wykluczyć przypadków głoszenia tych teorii po to, aby podjąć próbę skierowania sprawy

* Uniwersytet Łódzki, Wydział Prawa i Administracji, Katedra Postępowania Karnego i Kryminalistyki,joannamaria.jarecka@gmail.com.

${ }^{1}$ Również w akcie zgonu jako przyczyna śmierci podane jest prawdopodobne samobójstwo - zatrucie barbituranami (Horan 2015; Kaniewski 2006). 
na niewłaściwą drogę, a w efekcie «odciągnąć» od rzekomego wyjaśnienia okoliczności zdarzenia. Celem może też być wywołanie sensacji, zasianie niepokoju społecznego, podważenie wiarygodności i zaufania do organów śledczych oraz promowanie się przez głoszącego teorię, jako jedynie wiarygodnego podmiotu" (Sygit 2015, 166). Dokładnie taka sytuacja ma miejsce w sprawie dotyczącej śmierci Marilyn Monroe. Mnogość teorii spiskowych, również takich, które się wzajemnie wykluczają, skutkuje zaciemnieniem prawdziwego przebiegu zdarzenia i w efekcie uniemożliwia dotarcie do prawdy. Autorka zauważyła, iż takie teorie pojawiają się wtedy, gdy społeczeństwo nie ma dostępu do pełnej wiedzy o poczynionych ustaleniach dotyczących zdarzenia.

W artykule przedstawiono analizę kilku teorii dotyczących sposobu, w jaki zmarła gwiazda kina. Odkrycie prawdy o śmierci Marilyn Monroe przy obecnym stanie wiedzy na ten temat wydaje się niemożliwe. Celem pracy jest kryminalistyczna analiza błędów i zaniedbań popełnionych w śledztwie, porównanie teorii dotyczących śmierci artystki i usystematyzowanie faktów związanych z tym przypadkiem.

\section{DOŚWIADCZENIA ŻYCIOWE AKTORKI MAJĄCE WPLYW NA JEJ STAN PSYCHICZNY}

Marilyn Monroe urodziła się 1 czerwca 1926 r. w Los Angeles jako Norma Jean Mortenson (Kaniewski 2006) ${ }^{2}$. Śmierć aktorki mimo upływu czasu wciąż budzi emocje. Pojawiają się nowe wątpliwości, świadkowie zdarzeń z dnia, w którym zmarła, zmieniają zeznania. Co naprawdę wydarzyło się 5 sierpnia 1962 r., w dniu śmierci Marilyn Monroe? Aktorka, która była i jest uznawana za ikonę kobiecego piękna, w życiu prywatnym nie była szczęśliwa. Traumatyczne dzieciństwo sprawiło, iż artystka była niezrównoważona emocjonalnie, mówiła z charakterystyczną manierą imitującą głos dziecka, wybuchała salwami śmiechu w nieoczekiwanych momentach (Russell, Belmont 2000, 10). Nie potrafiła ułożyć sobie życia prywatnego. Pierwszy raz wyszła za mąż w wieku 16 lat - w 1942 r. poślubiła Jamesa Dougherty’ego (Taraborrelli 2009, 73-74)³. Małżeństwo jednak nie przetrwało długo (Horan 2015). Drugim mężem aktorki był Joe DiMaggio, gwiazda amerykańskiego baseballu. Sportowiec bił Marilyn Monroe i małżeństwo zakończyło się po zaledwie dziewięciu miesiącach (Capell 1964, 10). Trzecim mężem artystki był Arthur Miller, ale i ten związek nie trwał długo. Według niepotwierdzonych informacji aktorka mogła popełnić aborcję 12, a nawet 14 razy (Margolis 2014), co wpłynęło na jej bardzo zły stan emocjonalny.

${ }^{2}$ Norma Jean Baker to nazwisko widniejące w akcie urodzenia. Takie nazwisko podano również w akcie chrztu.

${ }^{3}$ Według niepotwierdzonych informacji aktorka zdecydowała się na ślub w tak młodym wieku, aby uniknąć kolejnego przeniesienia do rodziny zastępczej. 
Nie potrafiła czuć się bezpiecznie, szukała akceptacji, zrozumienia, nadużywała leków i alkoholu (Kaniewski 2006).

Marilyn Monroe nie miała szczęśliwego dzieciństwa. Nigdy nie dowiedziała się, kto był jej ojcem. Matka zaś zachorowała na schizofrenię i umieszczono ją w szpitalu dla osób chorych psychicznie, kiedy artystka była dzieckiem (Morgan 2014, 146-147). W rodzinie Marilyn Monroe już wcześniej występowały choroby psychiczne (Kaniewski 2006). Małą Normę Jean przenoszono do różnych rodzin zastępczych. Żyła ona w przekonaniu, że matka jej nie chciała, że była nikomu niepotrzebna. Monroe cierpiała na lęki nocne, bezsenność, bulimię i depresję, na co wpływ zapewne miało jej trudne i traumatyczne dzieciństwo (Horan 2015).

Dzieciństwo aktorki - jak stwierdził koroner - wpłynęło również na jej późniejszą decyzję o popełnieniu samobójstwa. Pozbawienie się życia wpisano do raportu koronera jako oficjalną przyczynę śmierci gwiazdy (Curphey 1972). Samobójstwo uważa się za rodzaj dobrowolnej śmierci (Hołyst 1983).

\section{CZY KONSTRUKCJA PSYCHICZNA MARILYN MONROE BYLA NA TYLE NIESTABILNA, ABY AKTORKA BYLA ZDOLNA DO POPEŁNIENIA SAMOBÓJSTWA?}

Biorąc pod uwagę powyższe argumenty, moim zdaniem na to pytanie należy odpowiedzieć twierdząco. Trudne dzieciństwo, a także niepowodzenia w życiu osobistym $^{4}$ sprawiły, że artystka bardzo cierpiała. Miała niskie poczucie własnej wartości, rozpaczliwie poszukiwała akceptacji, zrozumienia (Kaniewski 2006). Lekarze Ralph Greenson i Hyman Engelberg nie pomogli jej w pokonaniu traumy, przepisywali jej bardzo silne leki, m.in. środki nasenne z rodzaju barbituranów ${ }^{5}$. Marilyn przyjmowała leki przed zaśnięciem, aby móc spać i po przebudzeniu, aby móc wstać rano z łóżka. Często łączyła je z alkoholem, co było bardzo niebezpieczne. Gospodyni i pomoc domowa artystki twierdziła, że jej pracodawczyni czasem zapominała, że już przyjęła jedną dawkę leków i sięgała po następną (wywiad z Eunice Murray, 1980).

Marilyn Monroe aż czterokrotnie próbowała popełnić samobójstwo, w tym dwa razy po poronieniu (Horan 2015). Być może tak naprawdę nigdy nie chciała się zabić, a jej próby samobójcze miały na celu zwrócenie na nią uwagi otoczenia (Capell 1964, 27).

W związku z powyższą argumentacją należy uznać wersję, jaką przyjął koroner, za możliwą. Jednakże nie jest to jedyna teoria dotycząca śmierci Marilyn Monroe. Argumentem przemawiającym przeciwko temu poglądowi jest fakt, że

\footnotetext{
${ }^{4}$ Marilyn Monroe była trzykrotnie mężatką, wszystkie małżeństwa zakończyły się rozwodem.

${ }^{5}$ Między innymi lek o nazwie Nembutal (zob. Horan 2015).
} 
jak twierdzą jej przyjaciele, nie miała powodu, aby się zabić. Cierpiała na chorobę afektywną dwubiegunową i tuż przed śmiercią była w fazie maniakalnej to znaczy euforycznej. Udało jej się odnowić kontrakt z wytwórnią filmową FOX, jej gaża za film wzrosła dwuipółkrotnie, przygotowywała się do kolejnego ślubu z Joe DiMaggio. Według relacji jej przyjaciół w ostatnich dniach życia była bardzo szczęśliwa (Margolis 2011, 2). Bob Slatzer twierdził, że w rozmowie z nim na dzień przed śmiercią Marilyn Monroe snuła plany na następne dni i miesiące, co nie jest charakterystyczne dla osób, które chcą się zabić. Samobójcy zazwyczaj nie robią planów na przyszłość (Durieux, Verger, Hamelin 1999).

\section{TEORIE DOTYCZĄCE ŚMIERCI AKTORKI}

Teorii dotyczących śmierci Marilyn Monroe jest wiele, jednakże autorka artykułu skupiła się na kilku, jej zdaniem najbardziej zasługujących na uwagę. Jedna z nich wskazuje, że przyczyną śmierci artystki było zabójstwo, inna mówi o umyślnym lub o nieumyślnym przedawkowaniu leków.

Aby przyjąć wersję dotyczącą zabójstwa, należy się zastanowić nad tym, kto i z jakiego powodu chciałby zabić Marilyn Monroe. Istnieje teoria, według której rodzina Kennedych miała motyw, aby przyczynić się do jej śmierci (Horan 2015)6. Marilyn Monroe śpiewała 19 maja 1962 r. na urodzinach Johna Kennedy’ego. Sposób, w jaki wykonywała utwór Happy Birthday to You, mógł zwrócić uwage opinii publicznej na związek z jubilatem. Istnieją teorie, które sugerują, że służby odpowiadające za wizerunek prezydenta bądź osoby z rodziny Kennedych chciały nie dopuścić do ewentualnego skandalu. Jeanne Carmen oraz Bob Slatzer, przyjaciele Marilyn Monroe, w wywiadach telewizyjnych opowiadali o tym, że aktorka miała romans zarówno z Robertem, jak i z Johnem Kennedym. Według ich słów Monroe zwierzyła im się z tego, iż zagroziła Robertowi Kennedy'emu, że jeśli nie skontaktuje się z nią do niedzieli, to w poniedziałek zwoła konferencję prasową, na której opowie o relacjach łączących ją z braćmi (Durieux, Verger, Hamelin 1999; Kaniewski 2006). Poniedziałku jednak nie dożyła, gdyż w niedzielę tego samego tygodnia znaleziono ją martwą. Marilyn Monroe, zgodnie z relacją jej przyjaciół, prowadziła dziennik zwany „red diary”, co tłumaczy się jako „,czerwony pamiętnik", w którym zapisywała ze szczegółami rozmowy, które prowadziła z Robertem i Johnem Kennedym ${ }^{7}$. Bob Slatzer w wywiadzie telewizyjnym powiedział, że widział ten dziennik. Jednak po śmierci gwiazdy pamiętnika nigdy

${ }^{6}$ Jak twierdzą przyjaciele aktorki, miała ona romans z ówczesnym prezydentem USA Johnem Kennedym, a także jego bratem Robertem Kennedym, prokuratorem generalnym Stanów Zjednoczonych.

${ }^{7}$ Slatzer twierdził, że aktorka zapisywała w tym notesie również tajemnice państwowe, o jakich rozmawiali z nią bracia Kennedy. Ewentualne upublicznienie tych treści stanowiło poważne zagrożenie dla rodziny polityków (Horan 2015). 
nie odnaleziono. Pod koniec życia Monroe obawiała się, że ktoś ją podsłuchuje, nawet nosiła ze sobą woreczek z monetami, aby dzwonić z automatów (Horan 2015). Istnieje wielu świadków, którzy potwierdzają to, że artystka była podsłuchiwana, m.in. fryzjer prezydenta Mickey Song, któremu prokurator generalny przytoczył fragment rozmowy, jaką Song odbył z Marilyn Monroe w jej domu (Durieux, Verger, Hamelin 1999) ${ }^{8}$.

\section{OSTATNIE DNI ŻYCIA MARILYN MONROE}

Jak wyglądały ostatnie dni Marilyn Monroe i jej otoczenie tuż przed śmiercią? Aktorka mieszkała w Los Angeles w małym domku zbudowanym w stylu hiszpańskim. Jej psychiatrą i powiernikiem był dr Ralph Greenson. Monroe odbywała z nim długie sesje terapeutyczne, a także przyjmowała silne leki przepisywane przez niego. Doktor Greenson przydzielił jej do opieki panią Eunice Murray, która miała wykonywać obowiązki pomocy domowej (Kaniewski 2006). Bardzo angażował się w leczenie Marilyn Monroe, poświęcał jej dużo czasu, zapraszał ją do domu. Artystka poznała też rodzinę swojego lekarza. Eunice Murray również odgrywała dziwną rolę w życiu aktorki. Była kimś pomiędzy pielęgniarką a gospodynią domową. W domu Marilyn Monroe pracował również zięć Eunice Murray. Pełnił on funkcję „złotej rączki”. W dniu swojej śmierci Marilyn postanowiła zwolnić Eunice Murray i jej zięcia - Normana Jeffriesa (Durieux, Verger, Hamelin 1999).

Ostatnią osobą, która rozmawiała z Marilyn Monroe, był jej scenarzysta. Około godziny 22.00 ich rozmowę przerwał jakiś hałas. Artystka powiedziała, że sprawdzi, co to było i oddzwoni później. Nie oddzwoniła już (Horan 2015). To zachowanie aktorki również nie pasuje do wersji z samobójstwem, gdyż osoba, która pragnie je popełnić, nie deklaruje, że niedługo oddzwoni. Zgodnie z wersją wydarzeń przyjętą przez koronera śmierć Monroe nastąpiła o 3.40. Taka godzina widnieje w raporcie. Eunice Murray zeznała, że po godzinie 3.00 nad ranem zobaczyła światło pod drzwiami pokoju, w którym przebywała Marilyn Monroe. Zaniepokoiło ją to, więc zadzwoniła do doktora Greensona. Ten powiedział jej, aby wyszła na zewnątrz budynku i wybiła okno, a następnie pogrzebaczem rozsunęła zasłony i zobaczyła, co dzieje się z aktorką. Pani Murray zrobiła to, co polecił jej psychiatra i zobaczyła Marilyn Monroe nieprzytomną, leżącą na łóżku $\mathrm{z}$ twarzą skierowaną w stronę poduszki, na której leżała. Murray ponownie zadzwoniła do doktora Greensona. Lekarz powiedział jej, aby na niego poczekała. Niedługo po tym pojawił się w domu aktorki. Razem z gospodynią wybili okno

${ }^{8}$ Ostatecznie fakt, że aktorka była podsłuchiwana, został potwierdzony podczas remontu budynku, w którym mieszkała. Nowi właściciele domu artystki znaleźli tam skomplikowaną aparaturę podsłuchową. 
i weszli do pokoju, w którym leżała Monroe. Lekarz stwierdził zgon gwiazdy. Niedługo potem, według ich relacji, przyjechał również drugi lekarz Marilyn Monroe, Hyman Engelberg. Według oficjalnej wersji znaleziono ją o godzinie 3.40 (Durieux, Verger, Hamelin 1999; Kaniewski 2006; Capell 1964).

$\mathrm{W}$ tej historii istnieje wiele nieścisłości. Choćby ta, że pani Murray nie mogła zobaczyć światła pod drzwiami, gdyż kilka dni przed tym zdarzeniem aktorka poleciła położyć pod nimi grube dywany, które szczelnie zakrywały przestrzeń pod drzwiami (Kaniewski 2006).

O godzinie 4.25 nad ranem sierżant Jack Clemonds został poinformowany o znalezieniu martwej Marilyn Monroe (Capell 1964, 9). Pięć minut późnej był na miejscu. Sierżantowi pani Murray przedstawiła wersję, że całe zdarzenie miało miejsce nie o godzinie 3.00 nad ranem, ale o 1.00 . Gdy policjant zapytał, co przez te kilka godzin robili doktor Greenson i gospodyni, nie umieli oni udzielić odpowiedzi. Według zeznań policjanta zdenerwowało ich to pytanie. Oficerom, którzy przybyli później, przedstawili już inną wersję wydarzeń - przesuniętą o trzy godziny (Durieux, Verger, Hamelin 1999). Sierżant Clemonds relacjonował, że zobaczył Marilyn Monroe nagą, leżącą na łóżku z twarzą w kierunku poduszki, a jej prawa ręka zaciśnięta była na słuchawce od telefonu. Mogło to sugerować, że przed śmiercią próbowała wezwać pomoc. W pokoju było dużo pustych opakowań po lekach na receptę, ale nie było tam żadnej szklanki do popicia tych leków (Kaniewski 2006)9. Pokój również nie wyglądał jak pokój, w którym ktoś popełnił samobójstwo, zatruwając się barbituranami w formie tabletek (Durieux, Verger, Hamelin 1999). Nie było tam wymiocin, a w przypadku przyjęcia tak dużej dawki barbituranów organizm powinien się bronić poprzez wydalenie trującej substancji w postaci wymiotów. To jednak nie nastąpiło. Podczas śledztwa popełniono szereg błędów. Za błędne należy uznać już pierwsze założenie, które przyjęli oficerowie policji, iż w domu Marilyn Monroe nie popełniono przestępstwa. Skutkowało ono tym, że nie wykonano podstawowych czynności kryminalistycznych, nie zabezpieczono śladów, nie przesłuchano świadków. Najważniejsze są pierwsze godziny po zaistnieniu zdarzenia. Jeżeli ślady nie zostaną zabezpieczone w tym czasie, mogą przepaść bezpowrotnie. Poważnym błędem było to, że nie zebrano odcisków palców w domu Marilyn Monroe. Prześcieradło, na którym leżała aktorka, wyglądało - według zeznań Jacka Clamondsa - na świeżo zmienione. Oficerowie przybyli na miejsce zdarzenia między 4.00 a 5.00 rano i zauważyli, iż Eunice Murray robi pranie (Kaniewski 2006). Tej okoliczności nigdy nie zbadano. Nie zapytano nawet pani Murray, dlaczego robi pranie o tej porze w dniu śmierci swojej pracodawczyni. John Miner, zastępca prokuratora, stwierdził, że odrapania i otarcia na ciele Marilyn Monroe świadczą o tym, że ktoś przenosił ciało. Zeznania świadków tamtej nocy są w niektórych momentach sprzeczne. Eunice Murray

${ }^{9}$ Później szklanka została odnaleziona pod łóżkiem, jednak sierżant Clemonds był pewny, że wcześniej jej tam nie było (zob. Kaniewski 2006). 
w niektórych wywiadach twierdziła, iż znalazła Marilyn o północy, a w innych, że o godzinie 3.00. Na pytanie, co robiła przez trzy godziny zanim wezwała policję, w jednym z wywiadów odpowiedziała: „Nie wiem” (wywiad z Eunice Murray, 1980) (fot. 1).

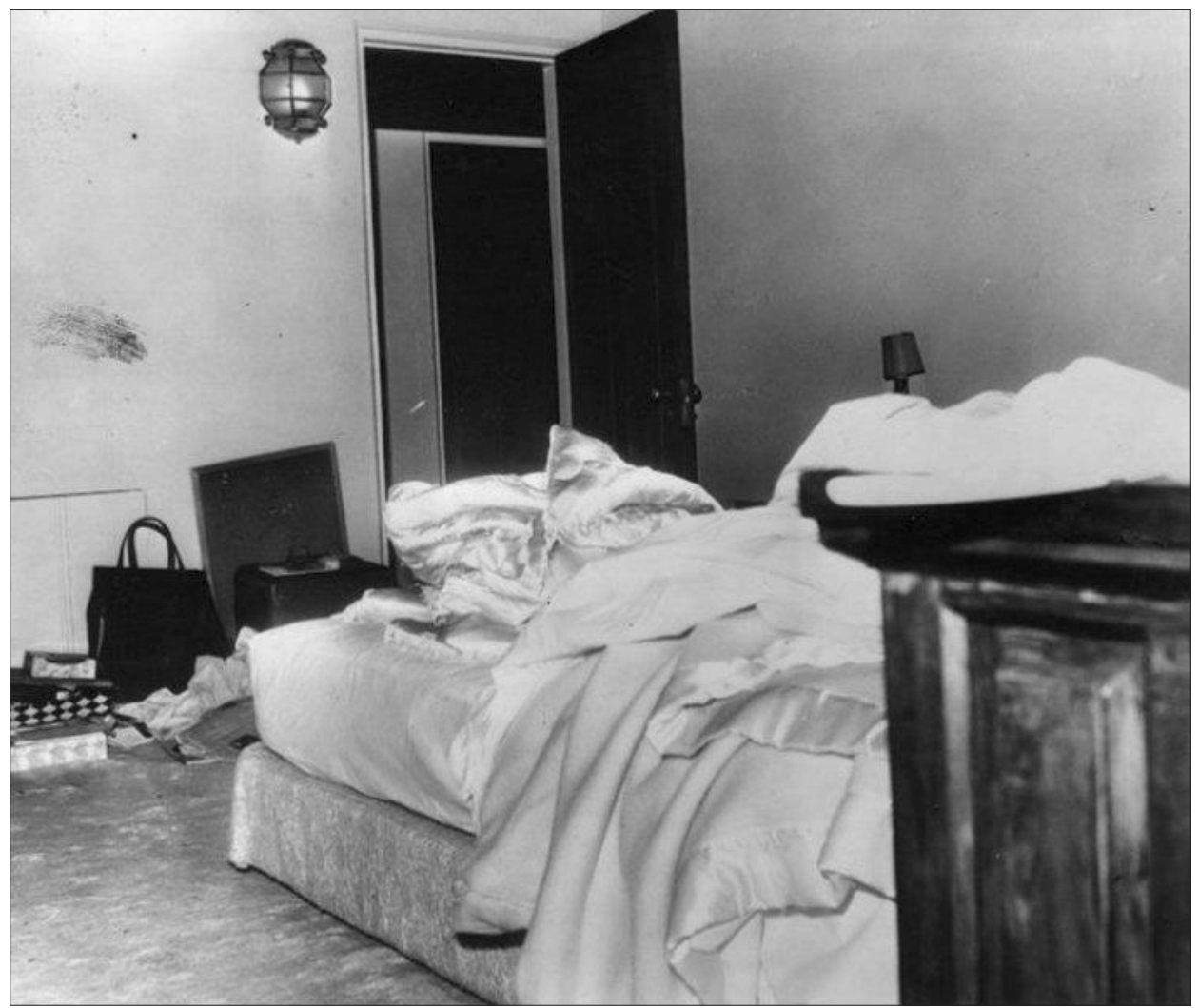

Fot. 1. Na jednym ze zdjęć zdarzenia widać czerwono-brunatną smugę na ścianie ${ }^{10}$

Źródło: Howe 2014

Nieprawidłowości miały miejsce również podczas sekcji zwłok aktorki. Autopsję przeprowadzał doktor Thomas Nagouchi. Z pobranych do analizy tkanek Marilyn Monroe zachowały się wyłącznie próbki wątroby, inne uległy zniszczeniu bądź zagubieniu (Horan 2015). Jest to tym bardziej zaskakujące, iż osoby zajmujące się tą autopsją wiedziały, że dotyczy ona sławnej aktorki. Miały świadomość, że przyciągnie to zainteresowanie mediów. Lekarz przeprowadzający

${ }^{10} \mathrm{Na}$ jednym ze zdjęć miejsca zdarzenia widać czerwono-brunatną smugę na ścianie. $Z$ trzech zdjęć tej ściany z miejsca zdarzenia tylko na jednym widnieje ta plama, na innych fotografiach przekazanych do mediów już jej nie widać. 
autopsję stwierdził, iż aktorka zmarła na skutek przedawkowania leków z grupy barbituranów ${ }^{11}$. W jaki jednak sposób szkodliwe substancje zostały wprowadzone do organizmu. Lekarz wykonujący sekcję zwłok nie stwierdził w żołądku artystki obecności żółtego barwnika. Nembutal, środek po zatruciu którym zmarła Marilyn Monroe, zawiera taki barwnik. Doktor Nagouchi stwierdził sino-różowe zabarwienie okrężnicy, co mogło sugerować, że aktorce tuż przed śmiercią zrobiono wlewkę doodbytniczą. W tej formie mogła zostać wprowadzona do organizmu śmiertelna dawka leków. Lekarz przeprowadzający sekcję zwłok stwierdził, iż dokładnie obejrzał ciało denatki i nie znalazł żadnych śladów po igle (Durieux, Verger, Hamelin 1999). Na jej ciele odkryto jednak siniaki, które mogły świadczyć o tym, iż przed śmiercią walczyła o życie (Kaniewski 2006).

John Miner, zastępca prokuratora, który $\mathrm{z}$ ramienia prokuratury zajmował się śledztwem, również otwarcie mówi o tym, iż jego zdaniem Marilyn Monroe padła ofiarą zabójstwa. Na pytanie, kto tego dokonał, w wywiadzie telewizyjnym odpowiedział: „Nie wiem” (Horan 2015).

W dniu śmierci Marilyn Monroe świadkowie widzieli w jej domu Roberta Kennedy'ego. Aktorka miała romans zarówno z Robertem, jak i z Johnem Kennedymi. Jej przyjaciele mówili o tym, iż liczyła ona na ślub z jednym z braci. Ci jednak nie zdecydowali się porzucić dla niej swoich rodzin (Kaniewski 2006). Johna Kennedy'ego Monroe poznała na przyjęciu u Petera Lawforda. Romans trwał aż do maja 1962 r. i zakończył się niedługo po tym, kiedy Marilyn zaśpiewała prezydentowi słynne Happy Birthday to You ${ }^{12}$. Aktorka, jak zeznawali jej przyjaciele, była $z$ tego powodu bardzo smutna, a niedługo po tym nawiązała romans z Robertem Kennedym. Prokurator generalny również zdecydował się zakończyć tę relację. Marilyn Monroe była zła i czuła się wykorzystana, dlatego miała zamiar zwołać konferencję prasową, podczas której chciała opowiedzieć dziennikarzom o swoich związkach z Kennedymi. Według relacji przyjació1 Marilyn Monroe prezydent i prokurator generalny rozmawiali z aktorką o tajemnicach państwowych. Ujawnienie tych informacji mogłoby skutkować skandalem (Kaniewski 2006). To jednak tylko hipoteza, na potwierdzenie której nie ma żadnych dokumentów.

\section{WĄTKI NIEPASUJĄCE DO OFICJALNEJ PRZYCZYNY ŚMIERCI ARTYSTKI}

W sprawie śmierci Marilyn Monroe istnieje wiele niewyjaśnionych, wręcz wykluczających się wątków. Jednym z nich jest zeznanie Nathalie Jacobs, żony Arthura Jacobsa. Powiedziała ona, że wieczorem w dniu śmierci aktorki była

${ }^{11}$ Silne leki na receptę.

${ }^{12}$ Utwór został wykonany w prowokacyjny sposób, który mógł wskazywać na intymną relację łączącą gwiazdę z prezydentem (zob. Kaniewski 2006). 
z mężem i ze znajomymi na koncercie. Między godziną 21.30 a 22.00 dostali telefonicznie informację, że artystka nie żyje bądź jest umierająca (Durieux, Verger, Hamelin 1999).

Jak zostało wcześniej wspomniane, policja popełniła w śledztwie wiele błędów. Jednym z nich było nieprzesłuchanie ważnych świadków, np. Normana Jeffriesa - zięcia Eunice Murray, który tamtej nocy przebywał w domu Monroe. $\mathrm{W}$ jednym $\mathrm{z}$ wywiadów dziennikarz relacjonuje rozmowę, jaką przeprowadził z Normanem Jeffriesem. Norman zatrudniony był u Marilyn Monroe jako „złota rączka" i zajmował się drobnymi naprawami. Powiedział on dziennikarzowi, że około 15.00-15.30 do domu Marilyn Monroe przyjechał Robert Kennedy wraz z Peterem Lawfordem. Jeffries twierdził, że prokurator generalny wysłał go wraz z gospodynią Monroe do sklepu. Po ich powrocie aktorka była roztrzęsiona i twierdziła, że Robert Kennedy jej groził (Margolis 2011, 39). O godzinie 22.00, zgodnie z zeznaniami Normana Jeffriesa, Robert Kennedy przyjechał raz jeszcze $z$ dwoma innymi mężczyznami. Polecono pracownikowi artystki, aby wyszedł. Kiedy wrócił, według jego relacji, Monroe leżała zsiniała na łóżku i nie oddychała. Wezwano karetkę, przeniesiono aktorkę z leżanki na podłogę, a doktor Greenson próbował zrobić pacjentce zastrzyk z adrenaliny w serce. Działo się to wszystko o godzinie 22.45 według relacji Normana Jeffriesa przekazanej przez dziennikarza (Horan 2015).

Robert Kennedy twierdził, że kiedy zmarła Marilyn Monroe, przez cały weekend był w San Francisco. W rzeczywistości kilku świadków widziało go w Los Angeles. Jednym z nich był Lynn Frankilin, policjant, który przypadkowo zatrzymał do kontroli drogowej samochód, w którym jechał Robert Kennedy wraz z Peterem Lawfordem (Wolfe 1998).

Do dnia dzisiejszego nie wiadomo, jaką rolę w tej układance odgrywała Pat Newcomb, agentka prasowa Marilyn Monroe. Twierdziła ona, że na dzień przed śmiercią aktorki jadła z nią kolację, a w noc przed śmiercią Monroe nocowała u niej w domu (Hanks 2015).

W 1982 r. wznowiono śledztwo, jednakże szybko, bo już po miesiącu, zamknięto je, podtrzymując wersję o samobójstwie. Jeanne Carmen twierdziła, że artystka na dzień przed śmiercią odbierała telefony z pogróżkami (Kaniewski 2006).

Bardzo dziwi fakt, że koroner przyjął wersję, iż Marilyn Monroe zmarła o 3.40, mimo iż stężenie pośmiertne ciała wskazywało na godzinę znacznie wcześniejszą. Zeznania gospodyni, która pierwotnie powiedziała sierżantowi Clemmondsowi, iż zauważyła światło pod drzwiami Marilyn Monroe około północy, również mogły sugerować inną godzinę śmierci. Ponadto sierżant ten został wydalony z policji. Jeżeli jednak śmierć artystki nastąpiła wcześniej niż wskazuje raport koronera, co przez ten czas robili pani Eunice Murray, doktor Greenson i doktor Engelberg? Skoro w domu Marilyn Monroe był zamontowany podsłuch, to być może gdzieś istnieje nagranie ostatnich chwil jej życia. 
Przytoczone fakty nie pozwalają na udzielenie jednoznacznej odpowiedzi, w jaki sposób zmarła aktorka. Możliwa jest zarówno wersja wydarzeń zakładająca samobójstwo, jak i zabójstwo. Jak wykazano w pracy, z jednej strony kilka osób miało motyw, aby dokonać zbrodni. $Z$ drugiej zaś - niestabilność psychiczna i życiowe problemy Monroe mogły być przyczyną podjęcia przez nią decyzji o samobójstwie. Popełnione w śledztwie błędy sprawiły, że niemożliwe jest szczegółowe odtworzenie ostatnich chwil życia artystki. W tej sprawie pojawiło się bardzo wiele wykluczających się informacji. Śledztwo prowadzono nierzetelnie, zaniedbując istotne szczegóły. Zbyt wiele niejasności w zeznaniach świadków nie pozwala też na zrekonstruowanie biegu wydarzeń tamtej nocy.

Ewentualne upozorowanie samobójstwa wydaje się wiarygodne z powodu zbyt wielu elementów wskazujących na zabójstwo. Świadczyłoby to jednak o dużej nieudolności osoby lub osób dokonujących tej pozoracji. Osoby mające motyw, aby pozbawić artystkę życia, miały wystarczające środki i możliwości, by nie popełnić takich błędów. Podchodząc do tej kwestii z drugiej strony, fakt iż pojawiają się $\mathrm{w}$ tej sprawie nazwiska prezydenta oraz prokuratora generalnego, mógł być motywem do próby skompromitowania tych osób.

B. Sygit, specjalista zajmujący się między innymi tematyką pozoracji, podczas jednego z wykładów dla studentów mówił o tym, że aby wykryć pozorację, należy szukać w danym zdarzeniu elementów nietypowych, niepasujących do reszty. Wydaje się, że w przypadku śmierci Marilyn Monroe było ich bardzo dużo: brak listu pożegnalnego, snucie planów na przyszłość, brak wymiocin w pokoju, świeżo pościelone łóżko, pranie, które robiła pani Murray, plama na ścianie, brak szklanki, sprzeczne zeznania świadków itd. Niejasności jest tak wiele, że trudno pokusić się o wyjaśnienie tego, co naprawdę wydarzyło się w noc śmierci Marilyn Monroe. Jeżeli prawdą jest, że istnieje nagranie z podsłuchu zamontowanego w domu aktorki, to być może kiedyś wyjdzie na jaw prawda o śmierci wielkiej gwiazdy kina.

\section{BIBLIOGRAFIA}

Capell, Frank A. 1964. The strange death of Marilyn Monroe. Bethel: Herald of Freedom.

Curphey, J. Theodore. 1972. Raport koronera z 17 sierpnia 1972. M. D. Chief Medical ExaminerCoroner County of Los Angeles.

Durieux, Jean, Fabienne Verger, Arnaud Hamelin. 1999. The ultimate investigation into a suspicious death. Sunset Presse Documentary.

Hanks, Tara. 2015. Immortal Marilyn. www.immortalmarilyn.com/pat-newcomb [dostęp 22.02.2017].

Hołyst, Brunon. 1983. Samobójstwo. Przypadek czy konieczność. Warszawa: Państwowe Wydawnictwo Naukowe.

Hołyst, Brunon. 2002. Suicydologia. Warszawa: LexisNexis.

Hołyst, Brunon. 2011. Wiktymologia. 325-334. Warszawa: LexisNexis. 
Horan, Don. 2015. Zamachy, które zmieniły świat. Tajemnica śmierci Marilyn Monroe. Film dokumentalny. Cz. 5.

Howe, Caroline. 2014. EXCLUSIVE - Bobby Kennedy ordered Marilyn Monroe's murder by lethal injection to prevent her from revealing her torrid affairs with RFK and JFK: New book sensationally claims to have finally solved the mystery surrounding her death. http:// www.dailymail.co.uk/news/article-2630449/EXCLUSIVE-BobbyKennedy-ordered-MarilynMonroes-murder-lethal-injection-prevent-revealing-torrid-affairs-RFK-JFK-dirty-Kennedyfamily-secrets-new-book-claims.html [dostęp 22.02.2017].

Kaniewski, Jarosław. 2006. Marilyn Monroe - blondynka, która wiedziała za dużo. Audiobook. Warszawa: Wydawnictwo Bellona.

Margolis, Jay. 2011. Marilyn Monore a case for murder. Bloomington: iUniverse.

Margolis, Jay. 2014. The Murder of Marilyn Monroe: Case Closed. Audiobook. Newark: Audible Studios.

Morgan, Michelle. 2014. Marilyn Monroe za kulisami. Wrocław: Wydawnictwo Dolnośląskie.

Murray, Eunice. 2013. Marilyn Monroe - The "I Don't Knows". https://www.youtube.com/ watch?v=yt6AlAapHO0 [dostęp 22.02.2017].

Russell, Jeane, Georges Belmont. 2000. Marilyn Monroe and the camera. Monachium: Schirmer art books.

Summers, Anthony. 2007. Goddess: The secret lives of Marilyn Monroe. London: The Orion Publishing Group.

Sygit, Bogusław. 2015. „O teoriach spiskowych ze stanowiska kryminalistyki”. W Ztota ksiega jubileuszowa Prof. Brunona Hotysta ,....ale prawdy szukaj w czynie”. 166. Warszawa: Fundacja Ubi societas, ibi ius.

Taraborrelli, J. Randy. 2009. „The secret life of Marilyn Monroe”. New York: Hachette Book Group. Wolfe, Donald. 1998. The Last Days of Marilyn Monroe. New York: HarperCollins.

\title{
Joanna Jarecka
}

\section{THE CRIMINALISTIC ANALYSIS OF THE CAUSES OF MARILYN MONROE'S DEATH}

\begin{abstract}
In the article, the author has analysed the mistakes and omissions in the investigation of Marilyn Monroe's death. How did she die? Was she murdered or was it a suicide? The paper is also the analysis of the psychological profile of the actress. The author has tried to recreate the circumstances of the actress's last life moments. The answers to the above questions are not the main purpose of the work. It is rather an attempt to induce an analysis by its recipient.
\end{abstract}

Keywords: Marilyn Monroe, homicide, suicide, evidence, autopsy. 